\title{
Application of a ternary phase diagram to the liquid-liquid extraction of ethanoic acid using ethyl ethanoate
}

\author{
Aline Amaral Madeira+(i)
}

Pontifical Catholic University of Minas Gerais (PUC-MG), 500 Dom José Gaspar Av, Belo Horizonte, Minas Gerais, Brazil

+ Corresponding author: Aline Amaral Madeira, email address: madeira.alineamaral@gmail.com

\section{ARTICLE INFO}

Article history:

Received: January 21, 2019

Accepted: March 9, 2019

Published: July 4, 2019

\author{
Keywords: \\ 1. ethanoic acid \\ 2. liquid-liquid extraction \\ 3. ternary phase diagram \\ 4. binodal curve \\ 5. tie-lines
}

\begin{abstract}
This article describes the liquid-liquid equilibrium of the extraction process of ethanoic acid $\left(\mathrm{C}_{2} \mathrm{H}_{4} \mathrm{O}_{2}\right)$ in aqueous phase using ethyl ethanoate as the solvent. The liquid-liquid extraction was modeled by the construction of a ternary phase diagram for the water/ethanoic acid/ethyl ethanoate system using the Origin software. The equilibrium data were experimentally obtained by titration at room temperature $(298.15 \mathrm{~K})$ and atmospheric pressure (101325 Pa) using four mixtures of water, ethanoic acid, and ethyl ethanoate. The determination of the composition of the extract and residue portions in the equilibrium of each mixture by of the tielines method allowed to examine the percentages of liquid-liquid extraction achieved. The distribution coefficients and separation factors calculated, made it possible an evaluation of the distribution and of the mutual solubility of the solute in the aqueous and organic phases. The results showed a good performance of ethyl ethanoate in the extraction of ethanoic acid for concentrations of solute until $16 \%$ of the feed.
\end{abstract}

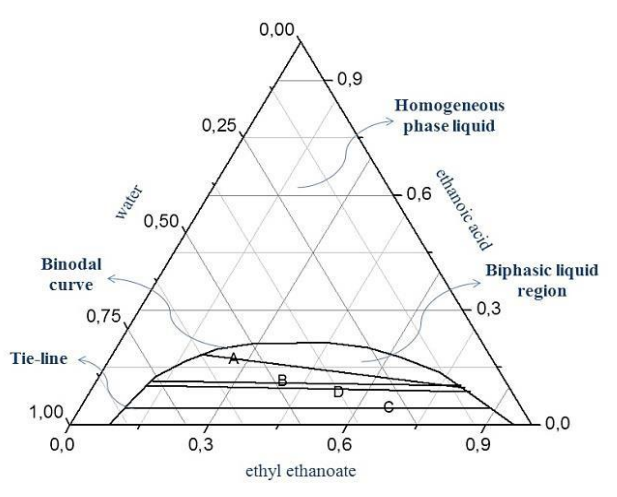

Ternary phase diagram for the water-ethanoic acid-ethyl ethanoate system

\section{Introduction}

Ethanoic acid $\left(\mathrm{C}_{2} \mathrm{H}_{4} \mathrm{O}_{2}\right)$ is one of the most widely used and important carboxylic acids in the world. Its wide range of applications includes its use as a raw material in the production of polymers derived from vinyl acetate, purified terephthalic acid, and esters of acetic anhydride and acetate, and as a solvent in the production of cellulose acetate and in the manufacture of pharmaceutical products $^{1,2}$. Its global market demand was 13 million tons in 2015 and is forecast to reach 18 million tons by $2020^{3}$.

The separation of the mixture of ethanoic acid and water is of great economic importance but is particularly difficult because it forms a pinch azeotrope. It is not a real azeotropic mixture, but the equilibrium concentrations of its constituents are very close and therefore requires many stages. For mixtures with concentrations below $40 \%$ ethanoic acid, the liquid-liquid extraction process is the most appropriate ${ }^{1}$.

Liquid-liquid extraction (LLE) is an important unitary operation employed in the chemical industry due to its high efficiency and low energy consumption and environmental impact. It is one of the most important mass transfer processes in chemical engineering and an alternative method to distillation ${ }^{4}$. Its efficiency is based on the physical and chemical properties of a solvent (organic phase) used to separate, purify or concentrate a certain constituent of an aqueous phase $\mathrm{e}^{5,6}$.

To design and optimize the LLE, liquid-liquid equilibrium data provided by ternary phase diagrams involving a solubility curve and tie-lines are required ${ }^{5}$. From the industrial point of view, 
knowledge of phase equilibrium is essential in modern process design and control methods ${ }^{4}$. Liquid-liquid equilibrium studies of systems composed of water, phenolic compounds and organic solvents are necessary for the evaluation of industrial units for solvent extraction processes ${ }^{7}$.

The equilibrium behavior of a three-component liquid-liquid system is typically described using a ternary phase diagram where experimental solubility data are plotted as points, which in turn lie in the binodal curve. The ternary phase diagram consists of an equilateral triangle where each side is divided into equal parts, corresponding to the mass fractions of each component of the system. The sides of the triangle represent the binary mixtures, while the vertices correspond to the pure components. Within the binodal curve, the biphasic liquid region is located, as well as the tie-lines that join the extract and residue streams in equilibrium, and outside, the homogeneous phase region ${ }^{8-10}$.

The spectrum of potential solvents for separation processes involving liquid-liquid extraction includes ethyl ethanoate, which has excellent properties for industrial applications, as well as being environmentally friendly and low cost, low toxicity and chemical stability ${ }^{11}$. Ethyl ethanoate has low toxicity compared to most organic solvents (benzene, toluene, chloroform) and its saturation temperature is considerably lower than other low toxicity solvents ${ }^{12}$.

In this context, based with the increasing worldwide demand for ethanoic acid, as well as in advantages of the use of ethyl ethanoate, the present article aims at studying the application of ternary phase diagram to the liquid-liquid extraction of ethanoic acid from aqueous phase using ethyl ethanoate as the solvent.

\section{Materials and methods}

\subsection{Binodal curve construction}

The liquid-liquid extraction process of ethanoic acid $\left(\mathrm{C}_{2} \mathrm{H}_{4} \mathrm{O}_{2}\right)$ realized was modeled by the construction of a ternary phase diagram for the water/ethanoic acid/ethyl ethanoate system at room temperature $(298.15 \mathrm{~K})$ and atmospheric pressure (101325 Pa). Initially, six points of the binodal curve for the water-rich phase were created by titration with ethyl ethanoate using $25.00 \mathrm{~mL}$ of water and the volumes of $0.00 ; 2.00 ; 4.00 ; 6.00$; 8.00 , and $10.00 \mathrm{~mL}$ of ethanoic acid in each point. The volumes of ethyl ethanoate, required for the turbidity of the aqueous solution containing ethanoic acid, were experimentally obtained and presented in Table 1. Subsequently, more seven points were created for the ethyl ethanoate-rich phase. For this, $25.00 \mathrm{~mL}$ of ethyl ethanoate and $0.00 ; 2.00 ; 4.00 ; 6.00 ; 8.00,10.00$ and $12.00 \mathrm{~mL}$ of ethanoic acid were used. The water expenses volumes were presented in Table 2.

Table 1. Experimental data of water-rich phase at $\mathrm{T}=298.15 \mathrm{~K}$ under $\mathrm{P}=101325 \mathrm{~Pa}$.

\begin{tabular}{cccc}
\hline \multirow{2}{*}{ Point } & \multicolumn{3}{c}{ Volumes (mL) } \\
\cline { 2 - 4 } & Water & $\begin{array}{c}\text { Ethanoic } \\
\text { acid }\end{array}$ & $\begin{array}{c}\text { Ethyl } \\
\text { ethanoate }\end{array}$ \\
\hline 1 & & 0.00 & 2.50 \\
2 & & 2.00 & 3.50 \\
3 & & 4.00 & 4.50 \\
4 & 25.00 & 6.00 & 7.00 \\
5 & & 8.00 & 10.40 \\
6 & & 10.00 & 15.90 \\
\hline
\end{tabular}

Table 2. Experimental data of ethyl ethanoate-rich phase at $\mathrm{T}=298.15 \mathrm{~K}$ under $\mathrm{P}=101325 \mathrm{~Pa}$.

\begin{tabular}{cccc}
\hline \multirow{2}{*}{ Point } & \multicolumn{3}{c}{ Volumes (mL) } \\
\cline { 2 - 4 } & $\begin{array}{c}\text { Ethyl } \\
\text { ethanoate }\end{array}$ & $\begin{array}{c}\text { Ethanoic } \\
\text { acid }\end{array}$ & Water \\
\hline 7 & & 0.00 & 0.90 \\
8 & & 2.00 & 2.40 \\
9 & & 4.00 & 4.00 \\
10 & 25.00 & 6.00 & 7.00 \\
11 & & 8.00 & 10.60 \\
12 & & 10.00 & 16.40 \\
13 & & 12.00 & 23.80 \\
\hline
\end{tabular}

\subsection{Tie-lines obtention}

Four mixtures (A, B, C, and D) were prepared using the volumes of water, ethanoic acid, and ethyl ethanoate described in Table 3. The preparation of each them was realized with magnetic agitation for 10 minutes at room temperature $(298.15 \mathrm{~K})$. Then, each mixture was submitted to one stage of extraction, compound by contact and separation. The ternary systems were made in contact by vigorous agitation in a separation funnel of $60.0 \mathrm{~mL}$ and were kept in repose for 5 minutes. The aqueous and organic phases were separated for a posterior measure of mass and volume. Aliquots of $5.00 \mathrm{~mL}$ of each phase were titrated with sodium hydroxide solution (NaOH) $1 \mathrm{~mol} \mathrm{~L}^{-1}$ using 3,3-bis(4-hydroxyphenyl)2-benzofuran-1-one $\left(\mathrm{C}_{20} \mathrm{H}_{14} \mathrm{O}_{4}\right)$ as the indicator. 
The volumes of $\mathrm{NaOH}$ expensed in each titration were presented in Table 4.

Table 3. Data survey for tie-lines obtention.

\begin{tabular}{ccccc}
\hline \multirow{2}{*}{ Component } & \multicolumn{4}{c}{ Volumes of the mixtures $(\mathbf{m L})$} \\
\cline { 2 - 5 } & $\mathbf{A}$ & $\mathbf{B}$ & $\mathbf{C}$ & $\mathbf{D}$ \\
\hline Ethyl ethanoate & 25.00 & 25.00 & 25.00 & 25.00 \\
Ethanoic acid & 8.00 & 5.00 & 2.00 & 4.00 \\
Water & 17.00 & 20.00 & 23.00 & 21.00 \\
\hline
\end{tabular}

Table 4. Titration data of the mixtures A, B, C, and D at $\mathrm{T}=298.15 \mathrm{~K}$ under $\mathrm{P}=101325 \mathrm{~Pa}$.

\begin{tabular}{|c|c|c|c|c|c|c|c|c|}
\hline \multirow[b]{2}{*}{ Mixture } & \multicolumn{4}{|c|}{ Aqueous phase } & \multicolumn{4}{|c|}{ Organic phase } \\
\hline & $\begin{array}{c}\text { volume } \\
(\mathrm{mL})\end{array}$ & $\begin{array}{c}\operatorname{mass} \\
(\mathrm{g})\end{array}$ & $\begin{array}{c}\text { volume } \\
\text { NaOH } \\
(\mathrm{mL})\end{array}$ & $\begin{array}{c}\text { mols } \\
{\mathrm{NaOH} / 10^{-3}}^{(5 \mathrm{~mL})}\end{array}$ & $\begin{array}{c}\text { volume } \\
(\mathbf{m L})\end{array}$ & $\underset{(g)}{\operatorname{mass}}$ & $\begin{array}{l}\text { volume } \\
\mathrm{NaOH} \\
(\mathrm{mL})\end{array}$ & $\begin{array}{c}\text { mols } \\
\mathrm{NaOH} / 10^{-3} \\
(5 \mathrm{~mL})\end{array}$ \\
\hline A & 17.00 & 15.79 & 14.30 & 14.30 & 33.00 & 30.47 & 14.40 & 14.40 \\
\hline B & 21.50 & 21.02 & 9.40 & 9.40 & 25.00 & 23.08 & 9.10 & 9.10 \\
\hline $\mathrm{C}$ & 25.00 & 24.26 & 3.60 & 3.60 & 25.00 & 23.07 & 3.30 & 3.30 \\
\hline D & 25.00 & 22.47 & 7.73 & 7.73 & 26.00 & 24.05 & 7.00 & 7.00 \\
\hline
\end{tabular}

\subsection{Plotting the equilibrium data}

The ternary phase diagram of water/ethanoic acid/ethyl ethanoate system was built using the Origin ${ }^{\circledR}$ software from of equilibrium data obtained in items 2.1 and 2.2. The volumes were converted in mass using the densities of each component at $298.15 \mathrm{~K}$ ( $\rho_{\text {ethanoic acid }}=1.052 \mathrm{~g} \mathrm{~mL}^{-1}$; $\rho_{\text {ethyl ethanoate }}=$ $0.901 \mathrm{~g} \mathrm{~mL}^{-1}$; and $\left.\rho_{\text {water }}=0.997 \mathrm{~g} \mathrm{~mL}^{-1}\right)$. The diagram was used to study the liquid-liquid extraction process of ethanoic acid $\left(\mathrm{C}_{2} \mathrm{H}_{4} \mathrm{O}_{2}\right)$ from aqueous phase with the use of ethyl ethanoate as the solvent.

\section{Results and discussion}

The equilibrium compositions in the binodal curve (in mass fraction) for each component of the water/ethanoic acid/ethyl ethanoate system at $298.15 \mathrm{~K}$ and $101325 \mathrm{~Pa}$ were given in Table 5. The same results were plotted in Figure 1. The area of the biphasic liquid region obtained results from the mutual solubility of the solute (ethanoic acid) in the aqueous and organic solvent (ethyl ethanoate).
Table 5. Mass fractions of the compounds of the ternary system at $\mathrm{T}=298.15 \mathrm{~K}$ under $\mathrm{P}=101325$ $\mathrm{Pa}$.

\begin{tabular}{ccccc}
\hline Phase & $\begin{array}{c}\text { Binodal } \\
\text { curve } \\
\text { point }\end{array}$ & Water & $\begin{array}{c}\text { Ethyl } \\
\text { ethanoate }\end{array}$ & $\begin{array}{c}\text { Ethanoic } \\
\text { acid }\end{array}$ \\
\hline & 1 & 0.9171 & 0.0829 & 0 \\
Water- & 2 & 0.8258 & 0.1045 & 0.0697 \\
rich & 3 & 0.7510 & 0.1222 & 0.1268 \\
& 4 & 0.6639 & 0.1680 & 0.1681 \\
& 5 & 0.5836 & 0.2194 & 0.1970 \\
& 6 & 0.5008 & 0.2878 & 0.2114 \\
\hline & 7 & 0.4030 & 0.3826 & 0.2144 \\
Ethyl & 8 & 0.3310 & 0.4560 & 0.2130 \\
ethanoate- & 9 & 0.2546 & 0.5427 & 0.2028 \\
rich & 10 & 0.1949 & 0.6289 & 0.1762 \\
& 11 & 0.1298 & 0.7332 & 0.1370 \\
& 12 & 0.0886 & 0.8336 & 0.0779 \\
& 13 & 0.0383 & 0.9617 & 0 \\
\hline
\end{tabular}




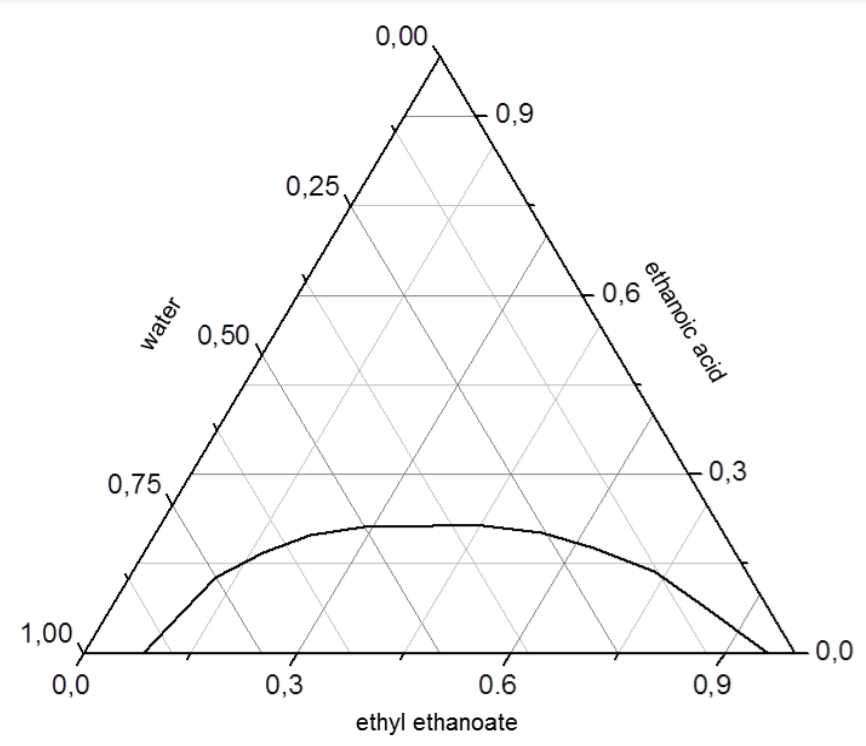

Figure 1. Ternary phase diagram of water/ethanoic acid/ethyl ethanoate system with binodal curve at $\mathrm{T}=$ 298.15 K under $\mathrm{P}=101325 \mathrm{~Pa}$.
The titration reaction involved in the volumetric analysis of ethanoic acid determination in each of the phases of the mixtures A, B, C, and D was presented in Equation 1. Since the reaction is 1:1, at the point of equivalence, the molar amount of ethanoic acid was equal to the sodium hydroxide. The formation of the reaction product, the acetate conjugate base $\left(\mathrm{CH}_{3} \mathrm{COO}^{-}\right)$, was easily identified by the use of the indicator 3,3-bis (4hydroxyphenyl)-2-benzofuran-1-one $\left(\mathrm{C}_{20} \mathrm{H}_{14} \mathrm{O}_{4}\right)$, which has a transition zone in the alkaline region.

$$
\mathrm{CH}_{3} \mathrm{COOH}+\mathrm{OH}^{-} \leftrightarrow \mathrm{CH}_{3} \mathrm{COO}^{-}+\mathrm{H}_{2} \mathrm{O}
$$

The mass fractions of ethanoic acid (MW $60.052 \mathrm{~g} \mathrm{~mol}^{-1}$ ), calculated from the equivalence of the number of moles of sodium hydroxide, as well as the mass fractions for the other components of the ternary system, found directly in the obtained diagram, were given in Table 6. The results obtained were plotted in Figure 2, where the tielines of each mixture were drawn.

Table 6. Mass fractions of the tie-lines of the ternary system at $\mathrm{T}=298.15 \mathrm{~K}$ under $\mathrm{P}=101325 \mathrm{~Pa}$.

\begin{tabular}{|c|c|c|c|c|c|c|}
\hline \multirow[b]{2}{*}{ Mixture } & \multicolumn{3}{|c|}{ Aqueous phase } & \multicolumn{3}{|c|}{ Organic phase } \\
\hline & $\begin{array}{c}\text { Ethanoic } \\
\text { acid }\end{array}$ & Water & $\begin{array}{c}\text { Ethyl } \\
\text { ethanoate }\end{array}$ & $\begin{array}{c}\text { Ethanoic } \\
\text { acid }\end{array}$ & Water & $\begin{array}{c}\text { Ethyl } \\
\text { ethanoate }\end{array}$ \\
\hline A & 0.1849 & 0.6253 & 0.1905 & 0.0965 & 0.0978 & 0.8055 \\
\hline B & 0.1155 & 0.7652 & 0.1201 & 0.1018 & 0.1026 & 0.7928 \\
\hline $\mathrm{C}$ & 0.0446 & 0.8558 & 0.0973 & 0.0430 & 0.0680 & 0.8890 \\
\hline $\mathrm{D}$ & 0.1033 & 0.7849 & 0.1126 & 0.0874 & 0.0907 & 0.8225 \\
\hline
\end{tabular}

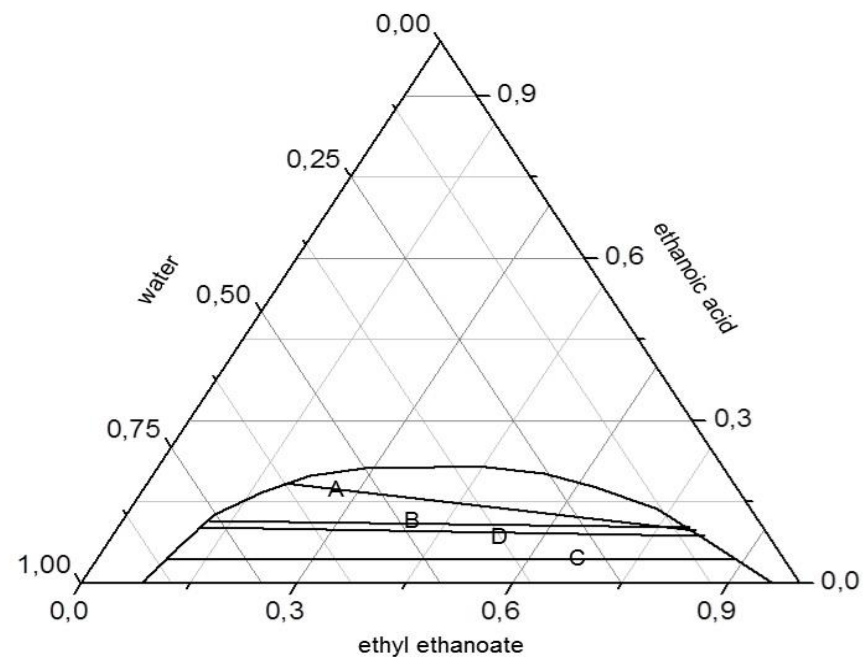

Figure 2. Ternary phase diagram of water/ethanoic acid/ethyl ethanoate system with the tie-lines corresponding to mixtures $\mathrm{A}, \mathrm{B}, \mathrm{C}$, and $\mathrm{D}$ at $\mathrm{T}=298.15 \mathrm{~K}$ under $\mathrm{P}=101325 \mathrm{~Pa}$. 
The results obtained in the study of liquid-liquid extraction for the water/ethyl ethanoate/ethanoic acid ternary system were summarized in Figure 3. The ethyl ethanoate free-base feed composition was represented by $\mathrm{F}$ point (water/ethanoic acid/ethyl ethanoate $=0.84 / 0.16 / 0$ ) and extractor solvent (pure) was represented by $\mathrm{B}$ point (water/ethanoic acid/ethyl ethanoate $=0 / 0 / 1$ ). The intersection between the FB segment and the tieline corresponding to the $\mathrm{D}$ mixture was represented by the $\mathrm{M}$ point, which in turn binds the extract $(\mathrm{E})$ and residue $(\mathrm{R})$ phases in equilibrium in the binodal curve. The equilibrium composition of the $\mathrm{E}$ and $\mathrm{R}$ phases in the mass fraction of ethanoic acid was of $\mathrm{Y}_{\mathrm{e}}=0.098$ and $\mathrm{X}_{\mathrm{r}}=0.102$, respectively.

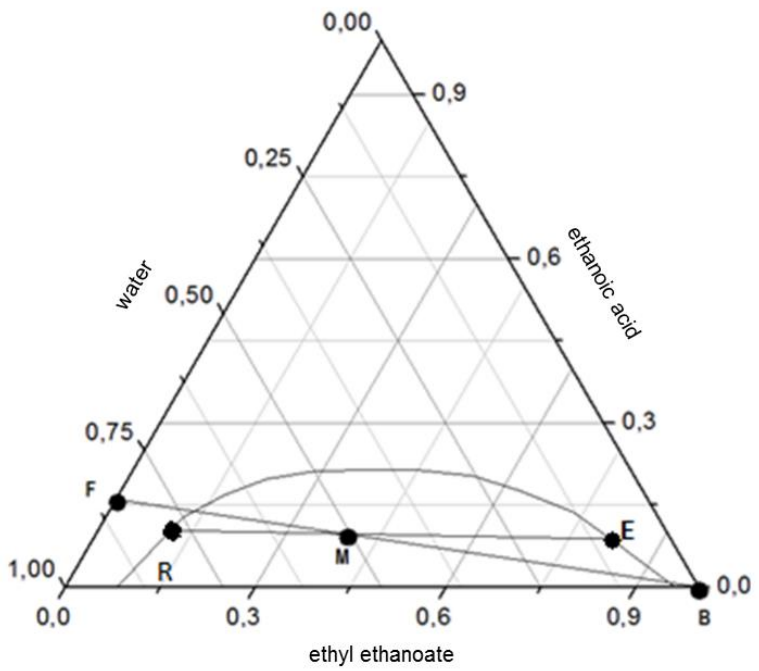

Figure 3. Ternary phase diagram of water/ethanoic acid/ethyl ethanoate system for mixture $\mathrm{D}$ at $\mathrm{T}=298.15$ $\mathrm{K}$ under $\mathrm{P}=101325 \mathrm{~Pa}$ (where F: feed; B: solvent; M: F + B mixture; E: extract, and R: residue).

The distribution coefficients (D) and the separation factors (S) for mixtures A, B, C, and D were calculated to evaluate the efficacy of extraction of ethanoic acid by the organic solvent (ethyl ethanoate) by Equation 2. The separation factor, which is a measure of the ability of a solvent to separate a solute from water, was defined as the ratio between the ethanoic acid $\left(D_{2}\right)$ and water $\left(D_{1}\right)$ distribution coefficients, respectively. The experimental values of the distribution coefficients and separation factors, for each mixture of the ternary system, were listed in Table 7.

$S=\frac{D_{2}}{D_{1}}=\frac{x_{E A, E E} / x_{E A, W}}{x_{W, E E} / x_{W, W}}$ where:

$\mathrm{S}=$ separation factor;

$\mathrm{D}_{1}=$ distribution coefficients for water;

$\mathrm{D}_{2}=$ distribution coefficient for ethanoic acid;

$\mathrm{x}_{\mathrm{EA}, \mathrm{EE}}=$ mass fraction of ethanoic acid in the ethyl ethanoate-rich phase;

$\mathrm{X}_{\mathrm{EA}, \mathrm{W}}=$ mass fraction of ethanoic acid in the waterrich phase;

$\mathrm{x}_{\mathrm{W}, \mathrm{EE}}=$ mass fraction of water in the ethyl ethanoate-rich phase;

$\mathrm{x}_{\mathrm{w}, \mathrm{w}}=$ mass fraction of water in the water-rich phase.

Table 7. Distribution coefficients for water $\left(D_{1}\right)$ and ethanoic acid $\left(\mathrm{D}_{2}\right)$ and separation factors $(\mathrm{S})$ at $\mathrm{T}=298.15 \mathrm{~K}$ under $\mathrm{P}=101325 \mathrm{~Pa}$.

\begin{tabular}{ccccc}
\hline System & Mixture & $\mathbf{D}_{\mathbf{1}}$ & $\mathbf{D}_{\mathbf{2}}$ & $\mathbf{S}$ \\
\hline Water + & $\mathrm{A}$ & 0.16 & 0.52 & 3.34 \\
Ethanoic & $\mathrm{B}$ & 0.13 & 0.88 & 6.57 \\
acid + & $\mathrm{C}$ & 0.08 & 0.96 & 12.13 \\
Ethyl & $\mathrm{D}$ & 0.12 & 0.85 & 7.32 \\
ethanoate & & & \\
\hline
\end{tabular}

The organic solvent chosen was found to have shown satisfactory separation factors (i.e. > 1), indicating its ability to extract ethanoic acid from water. The results demonstrated that the separation factor decreases in the order of the mixtures $\mathrm{C}>\mathrm{D}$ $>\mathrm{B}>\mathrm{A}$. For the ternary system, increasing the ethanoic acid content in the mixtures decreased the separating ability of ethyl ethanoate. The ethanoic acid distribution coefficients showed values higher than the water distribution coefficients, suggesting a higher preference of the solute to be distributed in the organic phase than in the aqueous phase.

The percentages liquid-liquid extraction (\%LLE) of ethanoic acid in water were determined for each mixture by tie-lines method and Equation 3 and can be checked in Table 8. The results suggested that the percentage extraction decreases in the order of the mixtures $\mathrm{D}>\mathrm{B}>\mathrm{C}>\mathrm{A}$, indicating that, for concentrations of ethanoic acid greater than $16 \%$ in $\mathrm{F}$, there was a reduction in the solvent extraction capacity. In short, ethyl ethanoate showed good performance in extracting ethanoic acid from the aqueous phase of the mixtures.

$\% L L E=\left(\frac{x_{F} F-x_{R} R}{x_{F} F}\right) \times 100$ 
where:

$\mathrm{X}_{\mathrm{F}}=$ feed mass fraction;

$\mathrm{X}_{\mathrm{R}}=$ residue mass fraction;
$\mathrm{F}=$ feed mass;

$\mathrm{R}=$ residue mass.

Table 8. Percentage liquid-liquid extraction (\%LLE) of ethanoic acid in the mixtures A, B, C, and D

\begin{tabular}{cccccccccc}
\hline Mixture & $\boldsymbol{x}_{\boldsymbol{F}}$ & $\boldsymbol{x}_{\boldsymbol{M}}$ & $\boldsymbol{x}_{\boldsymbol{R}}$ & $\boldsymbol{y}_{\boldsymbol{E}}$ & $\boldsymbol{F}$ & $\boldsymbol{M}$ & $\boldsymbol{R}$ & $\boldsymbol{E}$ & \% $\boldsymbol{L} \boldsymbol{L} \boldsymbol{E}$ \\
\hline A & 0.3318 & 0.1757 & 0.1849 & 0.0965 & 25.3650 & 47.8900 & 42.9255 & 4.9645 & 5.69 \\
B & 0.2087 & 0.1102 & 0.1155 & 0.1018 & 25.2000 & 47.7250 & 29.3135 & 18.4115 & 35.63 \\
C & 0.0840 & 0.0442 & 0.0446 & 0.0430 & 25.0350 & 47.5600 & 36.8250 & 10.7350 & 21.94 \\
D & 0.1673 & 0.0883 & 0.1033 & 0.0874 & 25.1450 & 47.6700 & 2.6190 & 45.0510 & 93.57 \\
\hline
\end{tabular}

In practice, it is believed that for mixtures with higher solute contents, the desired extraction percentage can be achieved by adopting mass transfer optimization strategies. Among them: an increase in the number of stages (contact and separation); an increase in the driving force of the process; favoring the flow of material of interest; increase in a concentration gradient etc.

\section{Conclusions}

The application of construction of a ternary phase diagram in the study the liquid-liquid extraction of the water/ethanoic acid/ethyl ethanoate system was quite satisfactory. The obtention of the equilibrium data of the ternary system made it possible an evaluation of the distribution and of the mutual solubility of the solute in the aqueous and organic phases. The determination of the composition of the extract and residue portions in the equilibrium of each mixture by of the tie-lines method allowed to examine the percentages of liquid-liquid extraction achieved by ethyl ethanoate. The acting of the solvent was evaluated by calculations of separation factors and percentage extraction, showing its good performance as an extractor solvent of ethanoic acid in the aqueous phase at room temperature and atmospheric pressure.

\section{References}

[1] García, N., Caballero, J. A., Economic and environmental assessment of alternatives to the extraction of acetic acid from water, Industrial \& Engineering Chemistry Research 50 (2011) 1071710729. https://doi.org/10.1021/ie201064x.

[2] IJmker, H. M., Gramblicka, M., Kersten, S. R. A., van der Ham, A. G. J., Schuur, B., Acetic acid extraction from aqueous solutions using fatty acids, Separation and
Purification Technology 125 (2014) 256-263. https://doi.org/10.1016/j.seppur.2014.01.050.

[3] Pal, P., Nayak, J., Acetic acid production and purification: critical review towards process intensification, Separation \& Purification Reviews 46 (1) (2017) 44-61. https://doi.org/10.1080/15422119.2016.1185017.

[4] Li, H., Wan, L., Chu, G., Tan, W., Liu, B., Qin, Y., Feng, Y., Sun, D., Fang, Y., (Liquid + liquid) extraction of phenols from aqueous solutions with cineole, Journal of Chemical Thermodynamics 107 (2017) 95-103. https://doi.org/10.1016/j.jct.2016.12.018.

[5] Wongsawaa, T., Hronec, M., Pancharoena, U., Phatanasri, S., Solubility and tie-line data for ternary aqueous mixtures of cyclopentanol with organic solvents at $\mathrm{T}=298.2 \mathrm{~K}$ : experiments and NRTL model, Fluid Phase Equilibria 379 (2014) 10-18. https://doi.org/10.1016/j.fluid.2014.07.011.

[6] Xu, D., Zhang, L., Gao, J., Pratik, D., Zhao L., Cui, Z., Liquid-liquid equilibrium for ternary systems of ethyl acetate/isopropyl acetate + 2,2,3,3-tetrafluoro-1propanol + water at 298.15, 318.15 K, Journal of Chemical Thermodynamics 106 (2017) 218-227. https://doi.org/10.1016/j.jct.2016.12.006.

[7] Gilani, H. G., Gilani, A. G., Sangashekan, M., Tieline data for the aqueous solutions of phenol with organic solvents at $\mathrm{T}=298.2 \mathrm{~K}$, Journal of Chemical

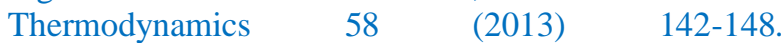
https://doi.org/10.1016/j.jct.2012.10.028.

[8] Lee, K. Y., Model to describe the binodal curve on a type 1 ternary phase diagram, Journal of Environmental $\begin{array}{lllll}\text { Engineering } & 136 \quad \text { (6) }\end{array}$ https://doi.org/10.1061/(ASCE)EE.19437870.0000196 .

[9] Pontifícia Universidade Católica de Minas Gerais. Equilíbrio líquido-líquido para o sistema água/acetato de etila/ácido acético, PUC Minas, Belo Horizonte, 2017. 
[10] Treybal, R. E., Mass-transfer operations, McGrall Hill Book Company, New York, 3rd ed., 1980.

[11] Yang, Z., Zhu, J., Wu, B., Chen, K., Ye, X., LiquidLiquid Equilibrium of (Water + Pentane-2,4-dione + Ethyl Ethanoate) and (Water + Pentane-2,4-dione + Cyclohexane) at (298.15 and 313.15) K, Journal of Chemical \& Engineering Data 55 (12) (2010) 57455750. https://doi.org/10.1021/je100704j.

[12] Cella, R. F., Mumbach, G. D., Andrade, K. L., Oliveira, P., Marangoni, C., Bolzan, A., Bernard, S., Machado, R. A. F., Polystyrene recycling processes by dissolution in ethyl acetate, Journal of Applied Polymer Science $135 \quad$ (18) https://doi.org/10.1002/APP.46208. 